\title{
Pembelajaran Calistung Menggunakan Metode Iqro' Pada Anak Untuk Membangun Generasi Rabbani Di Era Globalisasi
}

\author{
Siti Makhmudah Parti \\ STAIM Nglawak Kertosono Nganjuk \\ makhmudahsiti87@gmail.com
}

\begin{abstract}
Abstrak
Artikel ini didasarkan atas fenomena penggunaan metode iqro' pada pembelajaran membaca, menulis, berhitung (calistung), supaya anak merasa tertarik dan berminat untuk mengikuti proses pembelajaran tanpa ada paksaan. Sesuai dengan fenomena tersebut, penelitian ini difokuskan pada pertanyaan dasar, bagaimana penerapan Metode Iqro' pada pembelajaran membaca, menulis, berhitung (calistung)?. Untuk itu, penelitian ini bertujuan mendiskripsikan tentang: 1) latar belakang diterapkannya Metode Iqro' pada pembelajaran membaca, menulis, berhitung (calistung), 2) penerapan Metode Iqro' pada pembelajaran membaca, menulis, berhitung (calistung). Hasil makalah ini menunjukkan bahwa penerapan metode iqro' pada pembelajaran calistung di keaksaraan berdasarkan atas latar belakang anak yang lebih bisa mengaji/membaca huruf arab daripada membaca huruf alfabeth, penerapannya hanya dasar-dasarnya saja yang kemudian dikembangkan lagi dengan memberikan bacaan-bacaan pendek/ayat- ayat pendek yang disadur dari Al-Qur'an beserta pemaknaannya disertai tekhnik penyampaian yang menyenangkan telah mampu menjawab kebutuhan anak tentang belajar sehingga dapat menarik minat anak untuk belajar dan dalam penerapannya juga terdapat kelebihan antara lain Metode Iqro' dapat memberikan kemudahan bagi Tutor dalam menyampaikan materi dan bagi anak belajar mendapatkan kemudahan dalam menerima materi sedangkan kekurangannya antara lain jika anak belajar tidak rajin menghadiri proses pembelajaran, karena penerapan metode ini dilakukan secara beruntun atau bersambung. Sehingga semakin sering anak belajar tidak hadir maka akan semakin tertinggal, anak sama sekali tidak memahami huruf arab/ ataupun latin, karena permulaan penyampaian materi dengan menggunakan huruf arab. Kekurangan dalam penerapan Metode Iqro' tersebut jika tidak diatasi akan berimbas pada lambatnya proses pembelajaran.
\end{abstract}

Kata kunci: Islam, Iman, Ihsan, Matan Arba'in An-Nawawi, Materi Pembelajaran.

\section{Pendahuluan}

Akhir-akhir ini banyak masyarakat yang mulai peduli terhadap masa depan anak, sehingga banyak bermunculan lembaga pendidikan anak usia dini. Lembaga pendidikan anak usia dini merupakan salah satu bentuk pendidikan pra sekolah yang terdapat di jalur pendidikan sekolah (PP No. 27 Tahun 1990). Sebagai lembaga 
pendidikan pra-sekolah, tugas utamanya adalah mempersiapkan anak dengan memperkenalkan berbagai pengetahuan, sikap perilaku, keterampilan dan intelektual agar dapat melakukan adaptasi dengan kegiatan belajar yang sesungguhnya di Sekolah Dasar.

Pandangan ini mengisyaratkan bahwa lembaga pendidikan anak usia dini merupakan lembaga pendidikan pra-sekolah atau pra-akademik. Alur pemikiran ini tidak selalu sejalan dan terimplementasikan dalam praktik kependidikan lembaga pendidikan anak usia dini dan Sekolah Dasar di Indonesia. Karena banyak Sekolah Dasar mengajukan persyaratan atau tes "membaca dan menulis". Lembaga Pendidikan Sekolah Dasar seperti ini sering pula di anggap sebagai lembaga pendidikan "berkualitas dan bonafide".

Persoalan membaca, menulis, dan berhitung (calistung) memang merupakan fenomena tersendiri yang serba dilematis. Tidak jarang, orangtua yang memiliki anak usia dini merasa khawatir anak-anaknya tidak mampu mengikuti pelajaran di sekolah lanjutannya nanti (SD), jika dari awal belum dibekali keterampilan calistung. Akhirnya, banyak orangtua yang "memaksa" anaknya untuk belajar calistung, khususnya membaca.

Pada dasarnya pembelajaran calistung pada usia dini dinilai kurang tepat, karena seolah-olah memaksa anak yang masih dalam tahap pertumbuhan (anak masih senang bermain). Tetapi, praktik pendidikan di tingkat SD berbicara lain. Selama ini pendidikan
PAUD didefinisikan sebagai tempat untuk mempersiapkan anak-anak memasuki masa sekolah yang dimulai di jenjang SD. Kegiatan yang dilakukan di PAUD pun hanyalah bermain dengan menggunakan alat-alat bermain edukatif. Pelajaran membaca, menulis, dan berhitung tidak diperkenankan di tingkat PAUD, kecuali hanya pengenalan huruf-huruf dan angkaangka, itu pun dilakukan setelah anakanak memasuki TK B. Tetapi, pada perkembangan terakhir hal itu menimbulkan sedikit masalah, karena ternyata pelajaran di kelas satu SD sulit diikuti jika asumsinya anak-anak lulusan PAUD belum mendapat pelajaran calistung.

Karena tuntutan itulah, akhirnya banyak PAUD yang secara mandiri mengupayakan pelajaran membaca bagi murid-muridnya. Berbagai metode mengajar dipraktikkan, dengan harapan bisa membantu anak-anak untuk menguasai keterampilan membaca dan menulis sebelum masuk SD.

Sebagai muslim, sebetulnya kita sudah mempunyai cara jitu yang sesuai yaitu dengan mewajibkan anak-anak kelas A sudah menguasai materi iqro', minimal sudah menguasai iqro' jilid 1 . Iqro' adalah salah satu cara cepat mengajarkan anak-anak membaca huruf hijaiyah, yang merupakan huruf-huruf Al Qur'an. Semua muslim wajib mampu membaca Al Qur'an, karena Al Qur'an adalah pedoman hidup dunia akhirat. Firman Alloh yang pertama turun adalah Iqro', yang artinya bacalah. Belajar Iqro', tidak hanya akan 
mempermudah membaca huruf-huruf Al Qur'an, tetapi bisa juga sebagai sarana memudahkan kita mengajarkan membaca pada anak-anak usia dini.

Meskipun menurut para ahli usia anak siap untuk menerima pelajaran calistung adalah usia 7 tahun, tetapi mengenalkan huruf hijaiyah pada usia dini bukanlah hal yang buruk. Karena semakin cepat anak menguasai cara membaca huruf hijaiyah (Iqro'), makin cepat anak mampu membaca $\mathrm{Al}$ Qur'an. Dan Al Qur'an selain kumpulan Firman Allah juga merupakan kumpulan doa.

Begitu banyak keuntungan kita mewajibkan anak-anak usia 3-5 tahun untuk lancar membaca huruf hijaiyah. Keuntungan tersebut antara lain: kita membiasakan anak untuk membaca $\mathrm{Al}$ Qur'an sejak dini, membentuk karakter anak menjadi baik, dan memudahkan kita mengajarkan membaca pada anak usia dini.

Mengembangkan kemampuan para pendidik PAUD dan memberikan kiat-kiat untuk mengajar calistung secara menyenangkan, mungkin akan lebih baik daripada melarang pelajaran calistung pada anak usia dini secara keseluruhan, tanpa memberikan solusi untuk mengatasi persoalan baca-tulis di sekolah dasar. Bukan pelajarannya yang harus dipersoalkan, tetapi cara menyajikannya.

\section{Pembahasan}

Penelitian ini dilakukan selama dua periode tahun pelajaran yang berbeda di kelompok B, RA. Bening
Nurul Amin Banyupoh. Masing-masing siswa yang sudah dan belum lancar membaca iqro' jilid I ini dipisahkan menjadi 2 kelompok. Dari hasil pengamatan, biasanya begitu memasuki semester II, jumlah siswa yang lancar membaca meningkat. Hal ini seiring dengan perkembangan usia dan adanya "tuntutan" orang tua agar anaknya sudah lancar membaca begitu masuk ke SD.

\section{Iqro' Sebagai Salah Satu Cara Cepat Belajar Membaca Al Qur'an}

Mengapa sebagai muslim diharuskan untuk belajar membaca Alquran? Karena selain Al Qur'an merupakan kitab suci umat Islam, Al Qur'an juga membawa banyak sekali keutamaan bagi para pembacanya. Keutamaan yang paling besar ialah bahwa ia adalah kalam Allah, yang pujian terhadapnya telah difirmankan Allah di beberapa ayat seperti berikut:

1. "Dan, ini (Al Qur'an) adalah kitab yang telah Kami turunkan yang diberkahi." (Al-An'am: 92).

2. "Sesungguhnya Al Qur'an ini memberikan petunjuk kepada (jalan) yang lebih lurus." (Al-Isra': 9).

3. "Yang tidak datang kepadanya (Al Qur'an) kebatilan, baik dari depan maupun dari belakangnya." (Fushshilat: 42).

Dari hadis Utsman bin Affan r.a., bahwa Nabi SAW. bersabda, "Sebaikbaik orang di antara kalian adalah yang mempelajari Al Qur'an dan mengajarkannya." (HR. Bukhari). 
Belajar membaca

Qur'an merupakan hal yang sangat penting karena sebagai umat Muslim, kita tentunya berkewajiban untuk membaca Al Qur'an dalam keseharian kita. Bagaimana kita bisa mendekatkan diri dengan kitab suci umat Muslim ini jika kita tidak bisa membacanya?

Belajar membaca Qur'an pada awalnya terasa sangat sulit tetapi jika kita mau dan mampu berusaha untuk berlatih secara rutin walaupun dengan durasi waktu yang tidak banyak, dengan tekad kuat kita akan mampu membaca Alqur'a dengan lancar dan benar. Membaca Al Qur'an tidak hanya wajib bagi seorang Muslim yang sudah dewasa dan berakal sehat tetapi juga wajib untuk mengajarkannya pada anak-anak. Untuk itu sedini mungkin kita harus menerapkan konsep "wajib" ini di kepala kita sehingga kita merasa bahwa belajar membaca Alqur'an merupakan sebuah kebutuhan bagi kita umat Muslim. Setelah menerapkan konsep wajib ini, maka kita akan merasa lebih mudah untuk menjalaninya.

Buku Iqro' (Humam, 2000), merupakan cara cepat belajar membaca Al Qur'an. Buku ini mempunyai 10 kelebihan yaitu bacaan langsung, bersifat CBSA, bisa digunakan secara privat atau klasikal, praktis, sistematis, variatif, komunikatif, fleksibel, bersifat modul dan asistensi.

\section{Gambaran Pembelajaran Membaca Permulaan di RA}

Seperti sudah disebutkan di bab フ pendahuluan, bahwa metoda iqro lebih mudah dipahami anak membaca huruf hijaiyah. Hal ini juga diterapkan untuk membaca huruf latin.

Pada awal pembelajaran pra membaca, guru hanya menuliskan huruf hijaiyahnya terlebih dahulu dan anak-anak diminta mengucapkan. Contohnya suku kata ba. Guru menuliskan dahulu ب. Dan siswa sudah langsung mengucapkan ba. Selanjutnya guru hanya memberi tahu bahwa $=$ ba. Begitu pula untuk huruf yang lain. Guru hanya sedikit memerlukan kerja keras pada huruf latin yang tidak ada di huruf hijaiyah, seperti c dan p. Untuk kedua huruf ini guru bisa memberikan pembelajaran membaca suku kata awal kedua huruf ini setelah siswa sudah menguasai huruf-huruf lain yang ada di Iqro jilid I. Dan biasanya siswa akan mengikuti dengan sendirinya.

Selain itu di sekolah ini juga digunakan berbagai media dan metode untuk pembelajaran pra siswa kelompok B.Hal ini selaras dengan Depdiknas (2006), yang menyebutkan bahwa untuk memberikan rangsangan positif terhadap munculnya berbagai potensi keberbahasaan anak, permainan dan berbagai alatnya memegang peranan penting. Lingkungan (termasuk didalamnya peranan orang tua dan guru) seharusnya menciptakan berbagai aktifitas bermain secara sederhana yang memberikan arah dan bimbingan agar berbagai potensi yang tampak akan tumbuh dan berkembang secara optimal. Dengan media dan metoda yang selalu berganti dan tidak monoton, tampak antusias siswa dalam pembelajaran ini. 


\section{Kelompok Siswa Yang Sudah Menguasai Iqro' Jilid I}

Dengan berbagai media dan metoda yang digunakan pada pembelajaran membaca permulaan, tampak bahwa kelompok siswa yang sudah menguasai Iqro' Jilid I lebih mudah dan lebih cepat memahami daripada kelompok yang belum. Hal ini lebih memudahkan guru memberikan pembelajaran membaca permulaan. Sehingga pada tahap berikutnya, tanpa disertai dengan tulisan hijaiyah pun mereka lebih cepat untuk mengucapkan paduan suku kata.

Meskipun penggunaan media gambar sangat membantu, namun keefektifan media ini lebih baik bila didukung dengan kemampuan siswa menguasai iqro jilid I. Hal ini terlihat pada kelompok yang sudah menguasai iqro jilid I, jika mereka diberi gambar yang berbeda dan menemukan suku kata yang sama, mereka bisa langsung mengucapkan tanpa harus diterangkan lagi. Contohnya pada gambar bata dan baju.

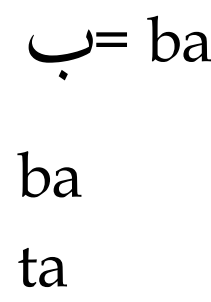

\section{ba ju}

Kedua kata ini berawalan suku kata yang sama yaitu ba, guru cukup menuliskan huruf بdi papan tulis untuk mengingatkan bunyi awal dari kedua kata tersebut. Hal ini tentu sangat membantu guru dalam melaksanakan tugasnya mengajarkan pra membaca pada siswa-siswanya. Dengan mewajibkan siswa-siswa menguasai iqro jilid I sebelum mereka masuk kelompok B, akan meningkatkan efektifitas pembelajaran pra membaca siswa. Karena siswa-siswa ini sudah paham dan hafal bila diberikan bacaan di Iqro jilid I.

\section{Perbandingan Siswa Yang Sudah dan Yang Belum Menguasai Iqro' Jilid I}

Dari hasil observasi tampak bahwa siswa-siswa yang lancar membaca terutama setelah akhir semester II adalah semua siswa yang sudah menguasai Iqro jilid I sebelum mereka masuk ke kelompok B. Sedangkan yang belum lancar membaca pada akhir semester II adalah mereka yang pada waktu masuk ke kelompok B belum menguasai iqro' jilid I.

Pada kelompok yang belum menguasai iqro jilid I, guru harus berulang-ulang mengajarkan bagaimana bunyi paduan huruf konsonan dan vokal a yang membentuk suku kata berakhiran a. Setiap berganti huruf konsonan, guru harus mengingatkan kembali bunyi paduan huruf konsonan sebelumnya. Contohnya: untuk mengajarkan bunyi fa, guru harus mengulang ba, da. Sedangkan pada kelompok yang sudah menguasai, guru cukup menuliskan huruf hijaiyahnya yang sesuai dengan paduan suku kata yang dimaksud. Hal ini sangat membantu guru dalam memberikan pembelajaran pra membaca. 
Pada awal pembelajaran pra membaca, siswa yang sudah menguasai iqro jilid I tetap mempelajari iqro jilid selanjutnya. Sehingga pada saat mereka diberi tulisan yang diakhiri dengan huruf vokal selain a, mereka sudah langsung mengerti. Guru cukup menuliskan huruf hijaiyahnya sekali. Contohnya suku kata bi, guru cukup menuliskan بsekali. Dan siswa sudah lancar untuk huruf-huruf berikutnya dengan sendirinya.

\section{Kesimpulan}

Mengembangkan kemampuan para pendidik PAUD dan memberikan kiat-kiat untuk mengajar membaca secara menyenangkan, mungkin akan lebih baik daripada melarang pelajaran membaca pada anak usia dini secara keseluruhan, tanpa memberikan solusi untuk mengatasi persoalan baca-tulis di sekolah dasar. Bukan pelajarannya yang harus dipersoalkan, tetapi cara menyajikannya. Cara penyajian yang variatif, dan tidak monoton seperti yang diterapkan diRA Bening Nurul Amin, tampak meningkatkan antusias siswa dalam pembelajaran ini. Apalagi bila diiringi dengan metoda reward /penghargaan bagi siswa, hal ini akan merangsang siswa untuk lebih meningkatkan kemampuannya.

Di kelompok B, digunakan berbagai media dan metoda cara belajar pra membaca, salah satunya menggunakan metode iqro'yang diadaptasi dari buku iqro' cara cepat membaca huruf Al Qur'an. Dari hasil observasi yang telah dilakukan selama dua periode tahun pelajaran di kelompok B, tampak bahwa kelompok siswa yang sudah menguasai iqro' jilid I sebelum mereka masuk ke kelompok B lebih mudah mengikuti pembelajaran membaca permulaan dan pada akhir semester II mereka sudah lebih lancar membaca.

Berbeda dengan kelompok yang belum menguasai iqro' jilid I sebelum mereka masuk ke kelompok B, siswasiswa ini membutuhkan waktu yang lebih lama dan harus terus diulangulang. Bahkan pada akhir semester II mereka belum begitu lancar membaca.

\section{Daftar Pustaka}

Depdiknas 2000. Permainan Membaca dan Menulis Di Taman KanakKanak. Jakarta: Depdiknas

Depdiknas. 2005. Kurikulum 2004 Taman Kanak-Kanak dan Roudlatul Athfal. Jakarta

Humam, As'ad. 2000. Buku Iqro' Cara Cepat Belajar Membaca Al Qur'an. Yogyakarta: Balai Litbang LPTQ Nasional.

http://www.sarjanaku.com/2011/10/ paud-penelitian-tindakankelas.html.

http://pemudapemikir.wordpress/201 1/8/ptk-taman-kanak-kanaktkra.html.

Musta'in, Nurani. 2010. Anak Islam Suka Membaca. Solo: Pustaka Amanah 